\title{
PHYSICAL PROPERTIES OF SANDCRETE-LATERITE BLOCKS
}

\author{
D.E. Ewa, J.O. Ukpata, E.A. Egbe and G.A. Akeke \\ Department of Civil Engineering, Cross River University of Technology, Calabar, Nigeria. \\ Corresponding Author: Email: desmondewa@crutech.edu.ng
}

Cite this article:

Ewa D.E., Ukpata J.O., Egbe E.A., Akeke G.A. (2022),

Physical Properties of Sandcrete-Laterite Blocks. International Journal of Mechanical and Civil Engineering 5(1), 1-9. DOI: 10.52589/IJMCE-3U4HBY35.

\section{Manuscript History}

Received: 15 Jan 2022

Accepted: 31 Jan 2022

Published: 10 Feb 2022

Copyright (C) 2022 The Author(s). This is an Open Access article distributed under the terms of Creative Commons AttributionNonCommercial-NoDerivatives 4.0 International (CC BY-NC-ND 4.0 ), which permits anyone to share, use, reproduce and redistribute in any medium, provided the original author and source are credited.
ABSTRACT: The incorporation of laterite in sandcrete blocks production is a common commercial practice in Nigeria. However, proper calibrations as per optimal mix proportions of these aggregates to give blocks that meet minimum requirements by various standards are lacking. In this study, a mix ratio of 1:8 (cement: aggregates) and a water-cement ratio of 0.5 was adopted at different percentages of laterite replacing sand. Block sizes of $450 \times 225 \times 150 \mathrm{~mm}$ were used. Curing was done for 3, 7, 14, and 28 days. A total of 104 blocks were prepared and tested for density, compressive strength, static modulus, water absorption and thermal conductivity. Results showed a decrease in density, compressive strength and thermal conductivity values with the addition of laterite. On the other hand, the water absorption of sandcrete-laterite blocks increased, as the blocks became more permeable. The decrease in thermal conductivity indicates better insulating properties of the Sandcrete-Laterite Blocks. These blocks will, therefore, reduce the energy requirements in a building. The study recommends an optimal replacement level of $10 \%$ of sand with laterite which gave a strength of $1.87 \mathrm{~N} / \mathrm{mm} 2$ and is $6.9 \%$ greater than the minimum requirement of $1.75 \mathrm{~N} / \mathrm{mm} 2$ by the Nigerian Building Code for individual blocks.

KEYWORDS: Sandcrete blocks, laterite, strength, static modulus, thermal conductivity. 


\section{INTRODUCTION}

There are heavy dependence and demands on sandcrete blocks as walling units in building infrastructures in Nigeria [1]. This has led to compromise on strength and other properties of blocks by suppliers. They tend to take advantage of this high demand and deliver low-quality blocks to prospective building developers. In addition, inadequate curing practices, poor compaction, and low cement content have also contributed to the low strength of sandcrete blocks available in Nigeria. In other to maximise profits, commercially available sandcrete blocks in Nigeria are below minimum standard strength. Researchers have established a trend of low compliance with standards concerning the compressive strength of sandcrete blocks produced commercially in most parts of Nigeria, $[2,3,4]$ and indicated that inadequate curing period by manufacturers of sandcrete blocks accounts for the low strengths of commercial sandcrete blocks observed. Adequate curing improved the strength of commercial sandcrete blocks by over $98 \%$ [4]. In different parts of Nigeria, sandcrete blocks form a major component of most buildings. Yet, its high cost has contributed partly to the non-realisation of adequate housing for both urban and rural dwellers [5]. Lateritic soil formation is a result of the chemical weathering process involving the profound transformation of primary rock-forming material into materials rich in the laterite constituents, namely: iron (Fe), aluminium (Al), titanium (Ti) and manganese $(\mathrm{Mn})$. The main factors which influence the nature of the end product, laterite and lateritic soils, are the parent rock types, the weathering condition determined by climate, topography and drainage conditions. These factors and the paedogenic process determine the morphology, chemical and mineralogy characteristics of the soils [5]. Lateritic soil possesses engineering properties that make it a potentially good and appropriate material for construction, especially for the construction of rural structures in developing countries. These advantages also include the non-requirement of specialised skilled labour for construction work. The strength of laterized concrete structures compares closely with those of normal concrete [6]. Lateritic soil abounds locally and its use is mainly limited to civil engineering works like road construction and landfill operations [7], it is less utilized in the building industry except as foundation backfill material. Different researchers have carried out works on partial replacement of sand with laterite in sandcrete blocks. According to [8], when sand is mixed with laterite fines, the most suitable mix for structural application is 1:1.5:3 (i.e. Cement: sand plus lateritic fines: gravel) with a water-cement ratio of 0.65 , provided that the lateritic content is kept below $50 \%$. It has also been established by [9] that the finer the grain size of lateritic soil, the higher the compressive strength of the unstabilised blocks made from such soil. Laterite formation processes form a factor in the strength determination and the compressive strength of lateritic soil is dependent on the source from which they were collected. [10] observed a $20 \%$ replacement of sand with laterite gave an average compressive strength of $2 \mathrm{~N} / \mathrm{mm}^{2}$, which satisfies the minimum requirements of [11] and [12]. In [13], coconut shell ash (CSA) was used to produce a sustainable cement-based material for sandcrete blocks. It was concluded that sandcrete blocks were eco-friendly and suitable for load-bearing masonry units as well as areas exposed to moisture. [14] reported on the utilization of red earth, lateritic soils, and quarry dust as alternate building materials in sandcrete blocks. For developing countries, red earth and quarry dust showed potential as an alternative to river sand in the construction of sandcrete blocks. 


\section{MATERIALS AND METHODS}

Natural river sand and laterite collected in bags were taken to the laboratory where they were dried for $48 \mathrm{hrs}$ to reduce the moisture content. Portland limestone cement grade 32.5 manufacture by UNICEM-LARFAGE conforming to [15] was used for the study. The cement was obtained in $50 \mathrm{Kg}$-bags and stored in an air-tight container to avoid ingress of moisture. Specific gravity and Particle size distribution test was conducted on the aggregates in accordance with [16]. A mix ratio of 1:8 (cement: aggregates) was adopted and 104 number block size of $450 \mathrm{~mm} \times 150 \mathrm{~mm} \times 150 \mathrm{~mm}$ were moulded. The blocks were cured for 28 days after 24 hours of demoulding by sprinkling with water in the morning and evening. Okhard Machine Tool's WA-1000B digital display Universal Testing Machine (UTM) machine with a testing range of $0-1000 \mathrm{kN}$ conforming to the requirements of [17] was used for compression test. The compressive strength of the blocks was determined using equation (1).

$$
f_{c}=\frac{P}{A}
$$

Where $f_{c}=$ the compressive strength,

$\mathrm{P}=$ crushing load, $\mathrm{A}=$ net cross-sectional area of the block.

The static modulus of elasticity was computed using equation (2) established by [18] as a function of the compressive strength and density of blocks.

$$
E_{c}=1.7 \rho^{2} f c^{0.33 * 10^{-6}}
$$

Were,

$E_{c}=$ Static modulus of Elasticity, $\rho=$ density, $f_{c}=$ compressive strength

Thermal conductivity of the blocks was obtained by subjecting them to heat treatment in a kiln up to $600{ }^{\circ} \mathrm{C}$. The temperatures at the inlet and outlet of the kiln were obtained using pyrometer and infrared thermometers respectively. Thermal conductivity was deduced from expression,

$$
\lambda=\frac{P}{L T}(3)
$$

Were,

$P=$ Power in Watt, $L=$ Length in meter, $T=$ Temperature in Kelvin

Power $($ Watt $)=$ Energy $($ Joules $) /$ Time $($ seconds $)$ and,

1 Joule $=0.0005265^{\circ} \mathrm{C}$. 
The results of the specific gravity for the materials used are shown in Table 1 . These values fall within the range specified by [18] for natural aggregates.

Table 1. Specific Gravity of materials

\begin{tabular}{llll}
\hline Material & Cement & River Fine & Lateritic Soil \\
\hline Specific Gravity, (Gs) & 3.15 & 2.75 & 2.61 \\
\hline
\end{tabular}

The particle size distribution curve of the aggregates is shown in the grading envelope of Figure. 1. The sand and laterite are well graded with the coefficient of uniformity $(\mathrm{Cu})$ of 7.5 and 10 respectively.

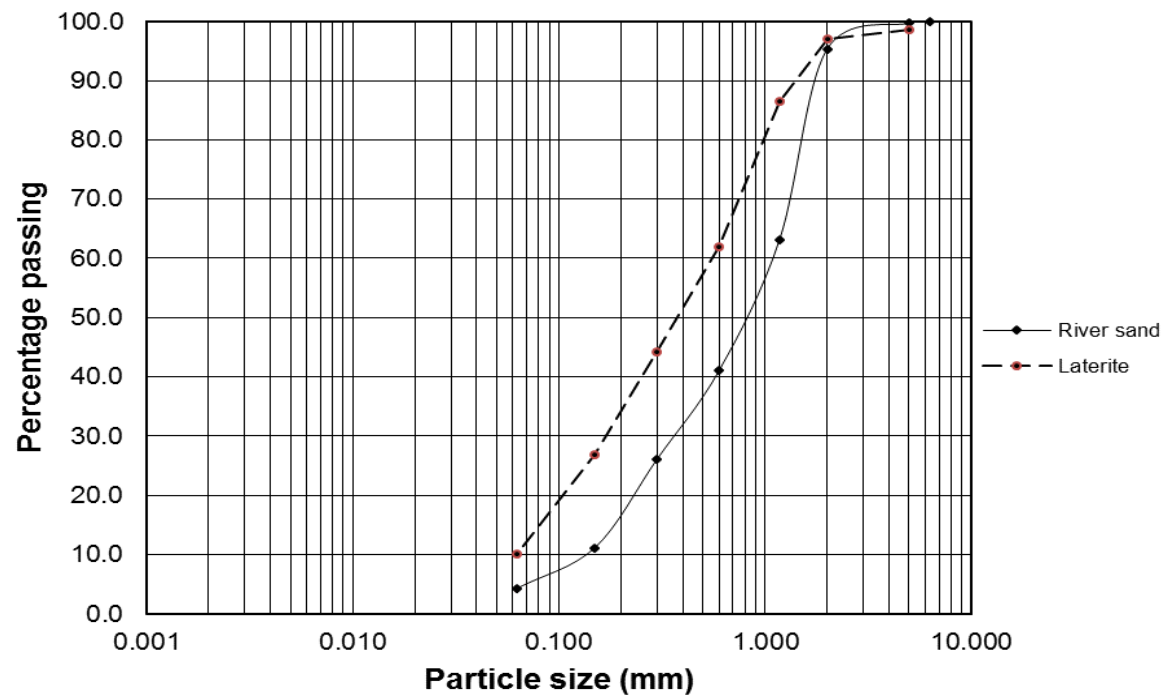

Figure. 1: Particle Size Distribution of sand and laterite

\section{RESULTS AND DISCUSSION}

\section{Density Of Sandcrete Blocks}

The variation of the density of sandcrete blocks with different percentage replacement of sand with lateritic soil is presented in Figure 2. Blocks with a high amount of laterite have lower densities than those made with sand $[10,18]$. This is attributed to the lower specific gravity of the lateritic material compared to sand. 


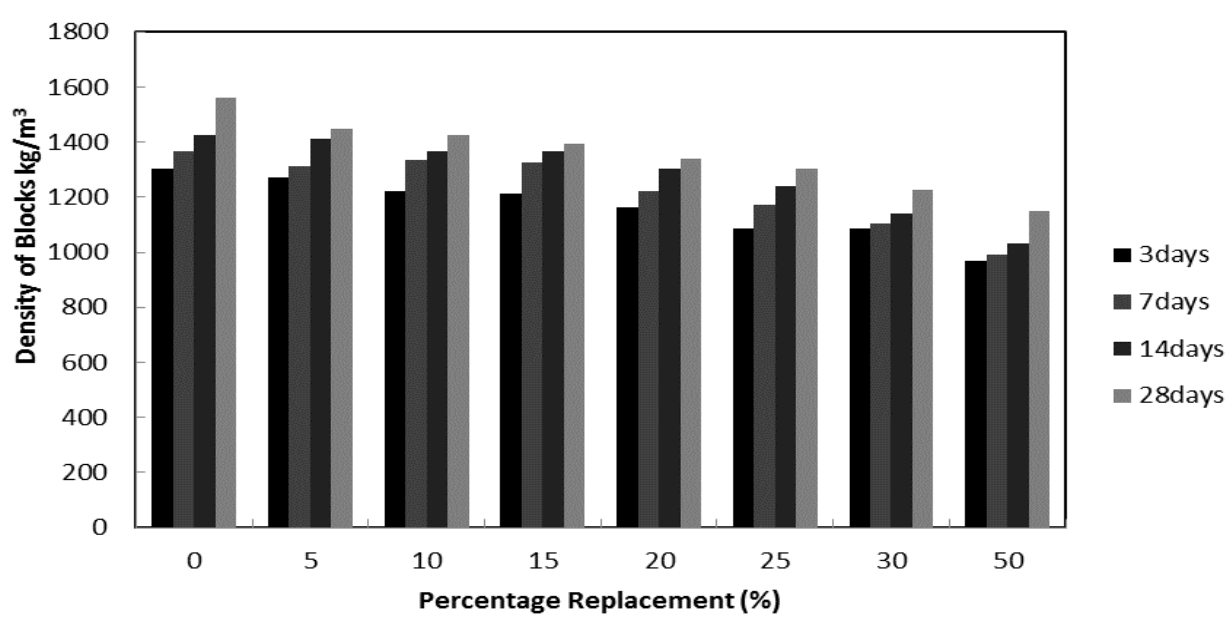

Figure. 2: Variation in Density of Sandcrete-Laterite Blocks

\section{Water Absorption}

Figure 3 shows the water absorption properties of the sandcrete-laterite blocks. There was a positive correlation between the laterite percentage and the quantity of water absorbed. The high-water permeability in the blocks was found to be associated with lower densities [20].

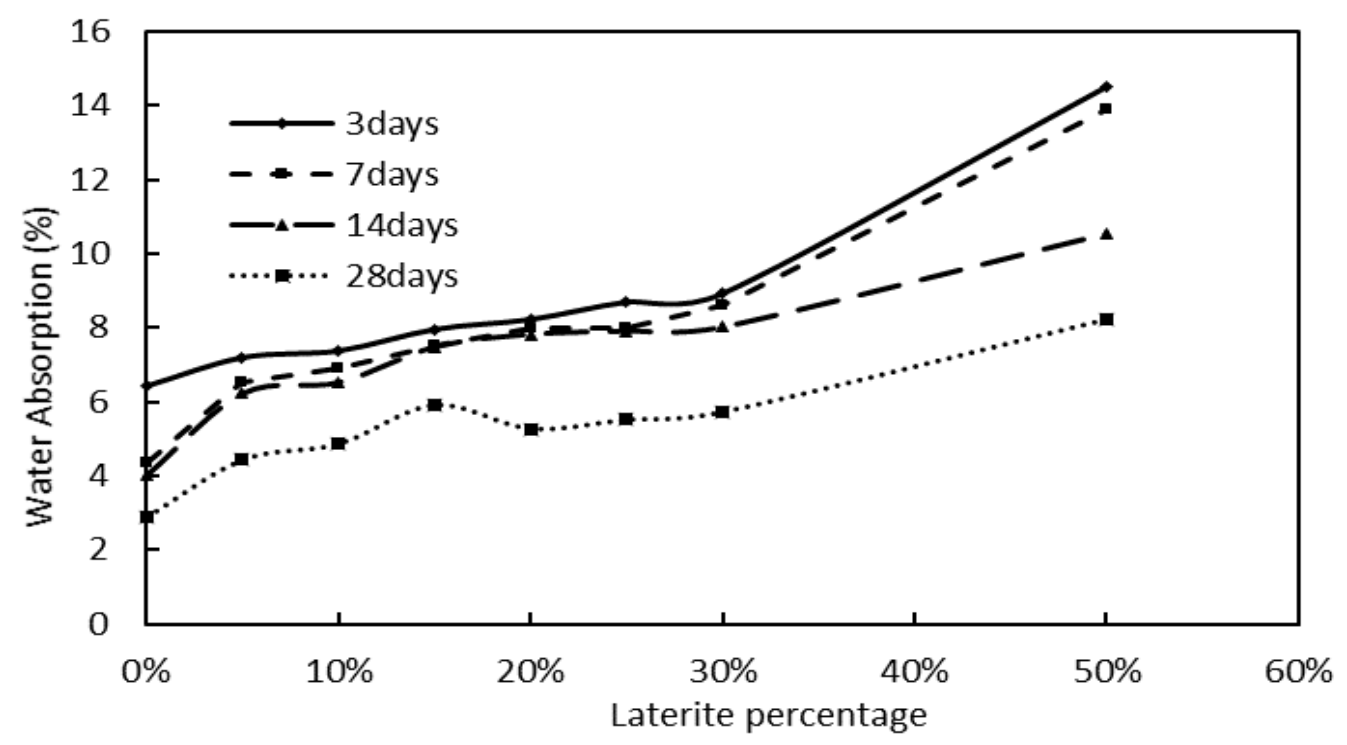

Figure 3: Water Absorption of Sandcrete-Laterite Blocks 


\section{Compressive Strength}

Variation in the compressive strength of sandcrete-laterite blocks is shown in Figure 4. Strength generally decreased as the percentage of laterite increases in the mix [19]. The 28-day strength of blocks decreased from $2.21 \mathrm{~N} / \mathrm{mm}^{2}$ at $0 \%$ laterite to $0.76 \mathrm{~N} / \mathrm{mm}^{2}$ at $50 \%$ laterite addition.

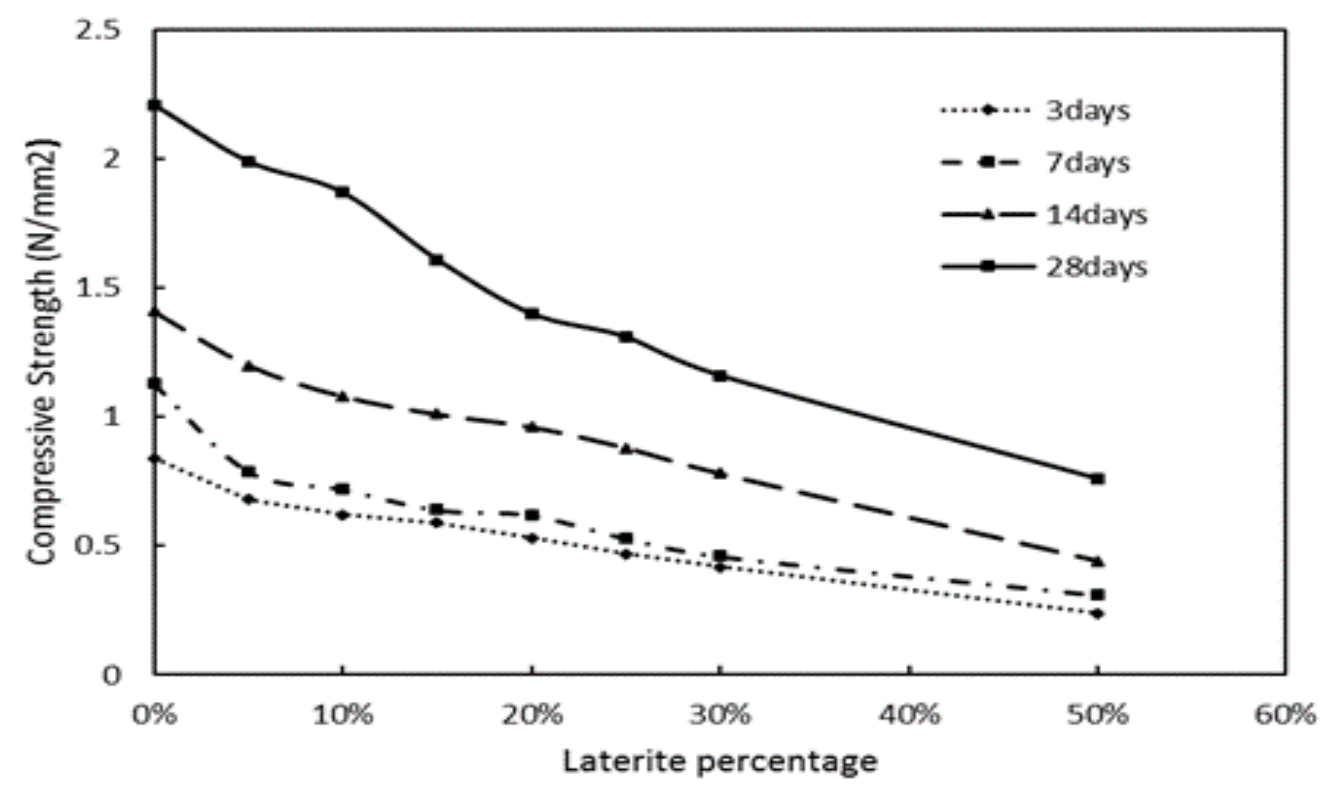

Figure 4: Compressive strength of Sandcrete-Laterite Blocks

\section{Static Modulus}

Static modulus is a function of compressive strength and density of blocks; these independent variables have a downward trend with the inclusion of laterite. The 28-day static modulus decreased from $5.37 \mathrm{GPa}$ at $0 \%$ to $2.05 \mathrm{GPa}$ at $50 \%$ laterite replacement of sand (Figure 5). This agrees with [20], the static modulus is dependent on the mix and strength of blocks. 


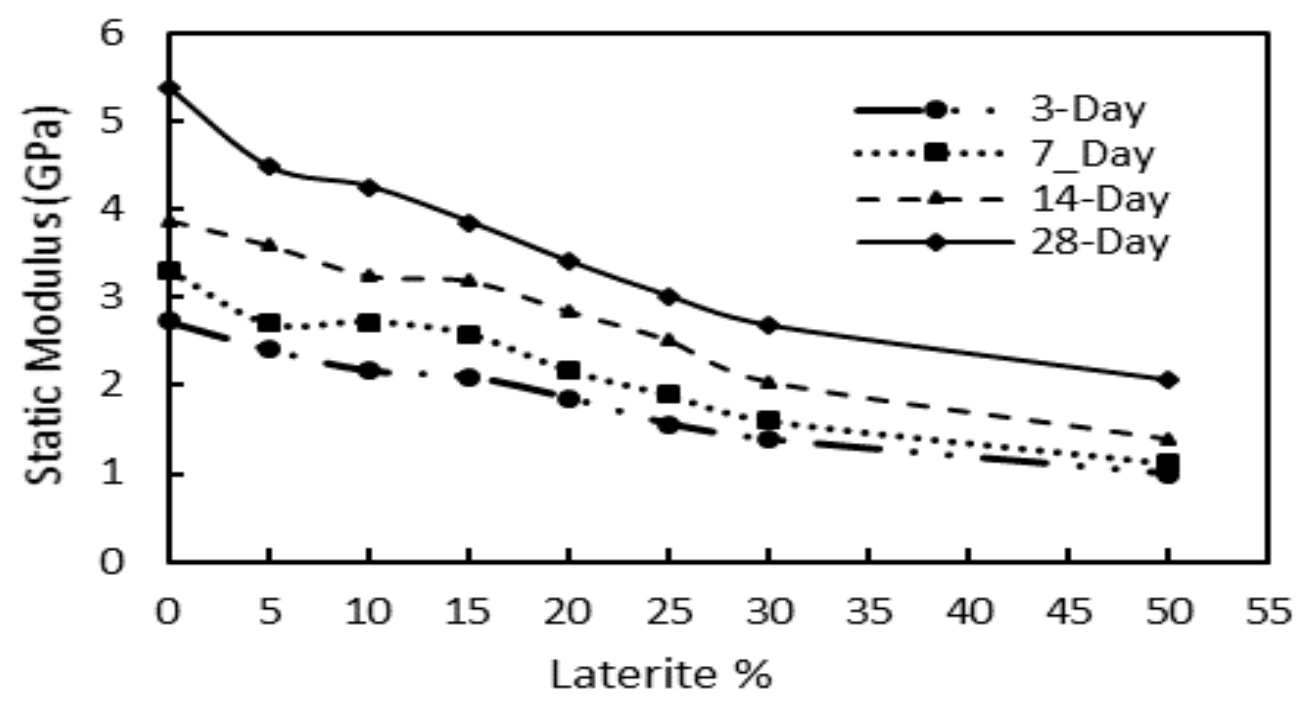

Figure 5: Static Modulus of Sandcrete-Laterite Blocks

\section{Thermal Conductivity}

The results show that thermal conductivity decreased from $1.12 \times 10^{-1} \mathrm{~W} /(\mathrm{mK}$ )at $0 \%$ laterite replacement of sand to $1.0 \times 10^{-2} \mathrm{~W} /(\mathrm{mK})$ at $50 \%$ replacement. These results show that sandcrete-laterite blocks have better insulating properties compared to the normal sandcrete blocks, (Figure 6). According to [19], blocks with higher thermal conductivity values are undesirable for hot climates such as Nigeria, due to an increase in the cooling/heating load requirement.

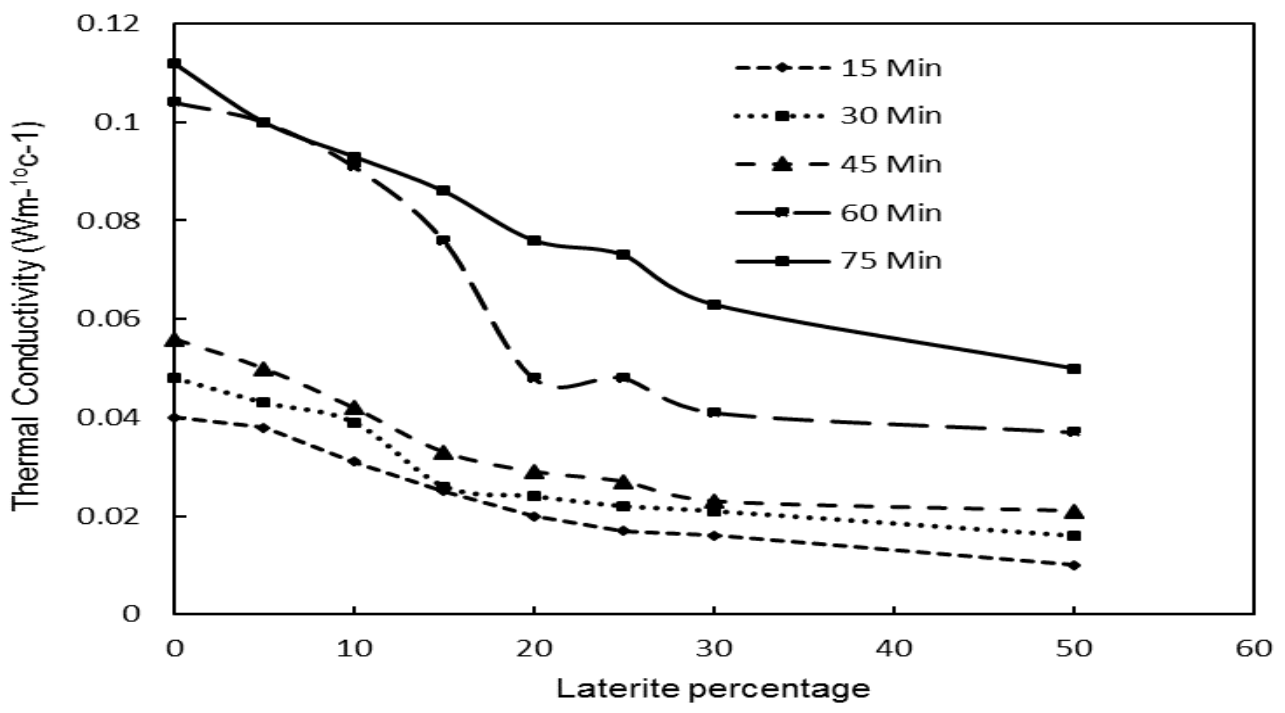

Figure 6: Thermal Conductivity of Sandcrete-Laterite Blocks 


\section{CONCLUSIONS}

The structural and thermophysical properties of sandcrete-laterite blocks were investigated. Laterite was added up to $50 \%$ replacement of sand and the density, compressive strength, static modulus, water absorption and thermal conductivity were reported. While there was a decrease in the density, compressive strength, static modulus and thermal conductivity of sandcretelaterites blocks, water absorption of the blocks increased. A 10\% replacement level of sand with laterite is recommended. This gave a strength of $1.87 \mathrm{~N} / \mathrm{mm}^{2}$ which is $6.9 \%$ greater than the minimum requirement of $1.75 \mathrm{~N} / \mathrm{mm}^{2}$ by the Nigerian Building Code for individual blocks.

\section{REFERENCES}

[1] M. Abdullahi, 2005. Compressive Strength of Sandcrete Blocks in Bosso and Shiroro Areas of Minna, Nigeria. Assumption University Journal of. Technology. 9(2): 126-132.

[2] Anosike, M., and Oyebande, A, 2012. Sandcrete Blocks and Quality Management in Nigeria Building Industry'. Journal of Engineering Project and Production Management. 2(1), 37-46.

[3] D.E. Ewa, J.O. Ukpata, 2013.Investigation of the Compressive Strengths of Commercial Sandcrete Blocks in Calabar Nigeria. International Journal of Engineering and Technology Volume 3 No. 4.

[4] Desmond E. Ewa, Joseph O. Ukpata, Anderson A. Etika, 2013. Effects of Curing on the Compressive Strengths of Commercial Sandcrete Blocks in Calabar Nigeria. International Journal of Engineering and Technology Volume 3 No. 7.

[5] Maignien, R 1966, Review of Research on Laterites. Natural Resources Research IV UNESCO, Paris.

[6] O. Joshua and P. O. Lawal. 2011. Cost Optimization of Sandcrete Blocks through Partial Replacement of Sand with Lateritic Soil. Journals Epistemics in Science, Engineering and Technology, Vol.1, No.2, 2011, 89-94.

[7] Akintorinwa, O. J, J. S and Olorunfemi, M. O, 2012. Geo-electric Reserve Estimation of Laterite Deposits Along a Basement Complex Underlain Osogbo-Iwo Highway, Southwest Nigeria. Journal of Emerging Trends in Engineering and Applied Sciences (JETEAS) 3 (3):490-496.

[8] L. A. Balogun and D. Adepegba, 1982. Effect of Varying Sand Content in Laterized Concrete. International Journal of Cement Composite Lightweight, 4, 235-241.

[9] Lasisi F and Ogunjimi B, 1984. Source and Mix Properties as Factor in the Characteristics Strength of Laterized Concrete. International Journal for Development Technology,2: 3,813.

[10] Joshua, O., Amusan, L. M., Fagbenle, O. I., and Kukoyi, P. O, 2014. Effects of Partial Replacement of Sand with Lateritic Soil in Sandcrete Blocks. Covenant Journal of Research in the Built Environment (CJRBE) Vol. 1, No. 2.

[11] Nigeria National Building Code 2006.

[12] NIS 978, Standard for Sandcrete Block, Standards Organisation of Nigeria, 2017.

[13] Chijioke Christopher Ikeagwuani, Donald Chimobi Nwonu, Chiagoziem Kanayo Ugwu, and Chukwudi Cajethan Agu (2020). Process parameters optimization for eco-friendly high strength sandcrete block using Taguchi method. Heliyon 6 (2020) e04276. https://doi.org/10.1016/j.heliyon.2020.e04276 
[14] Banjo, A. A., Alhassan, E., Aladegboye, O., Denen, T., A., and Owolaja Glory (2020). The use of red earth, lateritic soils and quarry dust as an alternative building material in sandcrete block. Scientific Africa 7(20) e00263. https://doi.org/10.1016/j.sciaf.2020.e00263

[15] BS EN 197-1:2011. Cement - Composition, specifications and conformity criteria for common types of cement. British Standards Institution.

[16] BS 1377-1:1990 Methods of test for soils for civil engineering purposes. General requirements and sample preparation. British Standards Institution, London.

[17] BS EN 12390-4:2000 Testing hardened concrete. Compressive strength specifications for testing machines. British Standard Institution, London.

[18] Neville A. M, 2011. Properties of Concrete, Pearson Education Limited, Edinburgh Gate, England. 5th Edition, p. 304-305.

[19] F. O. Okafor and E. A. Egbe 2017. Predicting Static Modulus of Elasticity of Laterite Quarry Dust Blocks Using Osadebe's Regression Model. IOSR Journal of Mechanical and Civil, Volume 14, Issue 1 Ver. IV (Jan. - Feb. 2017), PP 21-26

[20] G. L. Oyekan and O. M. 2011. Kamiyo A study on the engineering properties of sandcrete blocks produced with rice husk ash blended cement. Journal of Engineering and Technology Research Vol. 3(3), pp. 88-98. 